\title{
People's Behavior, in the Context of Living Standards Changes and Sustainable Development, Exemplified by the Carpathian Euroregion
}

\author{
Yuriy Bilan ${ }^{1}$, Katarzyna Chudy-Laskowska ${ }^{2}$, \\ Elżbieta Szczygiel ${ }^{3}$, Teresa Piecuch ${ }^{2}$
}

${ }^{1}$ University of Social Sciences, 9 Sienkiewicza St., 90-113 Łódź, Poland; Sumy State University, Ryms'koho-Korsakova St, 2, Sumy, Ukraine, y.bilan@prz.edu.pl

${ }^{2}$ Rzeszów University of Technology, Faculty of Management, Department of Quantitative Methods, Department of Enterprise Management, 8 Powstańców Warszawy St. 35-959 Rzeszów, Poland, kacha877@prz.edu.pl, tpiecuch@prz.edu.pl

${ }^{3}$ Pedagogical University of Krakow, Faculty of Social Science, Institute of Law and Economics, Department of Entrepreneurship and Social Innovation, 2 Podchorążych St. 30-084 Kraków, Poland, elzbieta.szczygiel@up.krakow.pl

\footnotetext{
Abstract: This paper is an attempt to present changes of living standards, as an element of sustainable development. In the article, the authors present a literature review concerning the sustainable development concept and its dimensions, as well as, its linkage with the living standard concept (and broadly - with the quality of life category). The main goal is a statistical analysis of the living standards of the inhabitants of the Carpathian Euroregion, which was conducted using the data from the years 2008-2016. Within the analysis, the authors presented three groups (clusters) of regions belonging to Euroregion and analyzed the differences between them, as well as, the main factors responsible for belonging to the applicable group. In the article, three hypothesis were examined. Only two of them were confirmed (one in limited scope).
}

Keywords: people's behavior; living standard; quality of life; sustainable development; the Carpathian Euroregion

\section{Introduction}

Generally speaking, the living standard refers to the objective, material-living conditions of a given society. On the other hand, a subjective evaluation of people happiness coming from meeting various needs or state of satisfaction in different 
areas of human life (e.g. social position, health, good education, various ways of spending free time etc.) refers to the quality of life. An important goal of sustainable development is to improve people's quality of life. There is a very strong relation between these categories. The higher living standard and - in effect - quality of life, results in paying more attention to climate or environment issues.

The lack of respect of sustainable development assumptions affects the large disproportions regarding the standard and quality of life. Only the meeting of sustainable development requirements (which means maintaining the balance between the economic, social and ecological dimensions) gives a guarantee of obtaining a higher standard and quality of life. Discussing these topics altogether makes the analysis more complex, it also draws attention to the well-being of the entire generation, living in particular historical circumstances (both poor and rich societies) with respect to natural resources and environmental requirements.

In the present paper, the standard of living was analyzed in the context of the sustainable development concept and was carried out for the Carpathian Euroregion. This area is highly diverse; therefore it creates a possibility to carry out a wide range of different research. A limited access to the data necessary for the analysis may be a problem, but nevertheless the research conducted can provide many interesting conclusions. The main thesis accepted in the paper stated as follows: socio-economic changes affect the similarity of areas within the Euroregion. In the analysis eleven indicators of the living standard were used. The analysis was carried out using chosen statistical methods: Cluster analysis (with Ward's method), Spearman's Rank correlation and Wilcoxon matched pairs test (for verification of the formulated hypotheses). The present analysis was conduct due to the fact, that the Carpathian Euroregion units the regions differing in many ways. The main aim of constitute the Carpathian Euroregion is to ensure the socio-economic development by supporting development processes in the field of territorial cooperation. The analysis of main factors influence on this process seems to crucial, but this subject is not so often taken into consideration (for ex. the number of scientific papers concerning the Carpathian Euroregion in SCOPUS database amount 13, while in Web of Science - only 8; in Google Scholar - 14). In 2023, the Carpathian Euroregion will celebrate the 30th anniversary of the uprising. It is needed, to deliver the consistent analysis of the development factors, influencing the selected parts of the Euroregion (regions) and allows for planning the strategical actions aiming at convergence of whole. The present analysis refers to the latter one, concerned with the standard of living of the Carpathian Euroregion's inhabitants [44], but now is expanded: the time span covers years 2008 and 2016, and the indicators have been divided into two groups. 


\section{The Quality of Life and Living Standard as an Element of Sustainable Development Concept - Literature Review}

\subsection{Sustainable Development as a Base for Activities Related with Increasing the Quality of Life}

The most common definition of the sustainable development has been written in Brundtland Report [8]. It has stated that sustainable development is "a development that meets the needs of the present without compromising the ability of future generations to meet their own needs". Although, these matters have been already discussed (ex. in Stockholm Declaration) [58], [33], the concept of sustainable development based on the Brundtland definition and - despite many inconsistencies [26] - is constantly developing. This positive undertone of that definition is more and more often replaced by the doubts regarding the possibilities of achieving it. As J. Stiglitz, A. Sen and J-P. Fitoussi have written [52]: Sustainability poses the challenge of determining whether we can hope to see the current level of well-being at least maintained for future periods or future generations, or whether the most likely scenario is that it will decline. Nevertheless, the attempts to achieve the sustainability of the economy (or wideunderstanding - our development as the humanity) require the standardization of terms used during the discussion. Using this concept in a variety of contexts affects limitation of its credibility, called into question its practical application and the significance of associated achievements and, overall, limited the progress in environmental and social developments which it was designed to underpin [30], [11], [42]. It causes the need to define this concept every time when it is used, as well as operation, e.g. while carrying out the statistical analysis with the use of the set of the given indicators [2], [53]. Reviewing the definitions, one can state that the most often characteristic features appearing in the papers are: conserving resources for future generations [15], high environmental, economic and sociocultural standards of living within the earth's endurance [50], [63] level of education and competencies [59], [62], social justice today and in the future [25], [26].

Most authors agree that the sustainable development has three dimensions (pillars): society (with a culture), environment and economy [6], [12], [13], [15], [19], [23], [38], [50] ${ }^{1}$. These dimensions' merge and penetrate each other. The relations between them are different and depend on the dimensions, e.g. between

It is worth noticing that some authors suggest other concepts, e.g. the relationship between human society and nature [19], [49] or using four dimensions (adding "institutional" [51], but we can assume that all of them are based on primary relation between "economic" and "environment" [37], [64]. 
"economy" and "environment" it should be viable, which means that the economic side of the development process concerns the humanity, and it should be conducted respectfully of the natural resources we have and use [61], [16]. Today's societies should not behave as the sole owners of the natural resources, but ought to think about future generations and their possibility to use them. The relation between "environment" and "society" should be bearable, which means that both aspects should be considered as equally important, without any preference or distinction. We could define the optimal relation between "economy" and "society" as equitable. Omission of any element affects that the development should not be sustainable, which implies a balanced development in economic, socio-cultural aspects without damaging environment [61]. These "pillars" approach allows to show the interconnection between the different spheres and - due to this - it is easy to understand the final effects. R. Emas [15] stated, that the main goal of sustainable development is the long-term stability of the economy and environment through the integration and acknowledgement of economic, environmental, and social concerns throughout the decision making process. It seems that the final receivers of all those efforts are people, and the same long-term stability in various aspects also guides other concepts, e.g. the quality of life [65]. Using different-time perspective in sustainable development activities caused taking into consideration the strength of the activities carried out. Similarly, as we can consider weak and strong sustainability [4], [15] or other variants [17], so we can think about different spheres of our life which should be improved. Sustainability development is perceived as an unashamedly anthropocentric concept [18], [33] because each of its element serves finally to an increase of the humans' well-being. This situation caused that each efforts for balanced improvement in the mentioned sustainable development's pillars should lead to increasing quality of life.

\subsection{The Environmental Aspects in Quality of Life and Living Standard Measurement}

Similarly, to sustainable development, the quality of life and related with it standard living concept - are also categories without the common definition. We assume that quality of life has multi-dimensional character, which broadly encompasses how an individual measures the 'goodness' of multiple aspects [48], [56]. Intangible, immeasurable issues, which are related with the quality of life sphere, should be operated into objective measures (a set of indicators) [44]. However, this process is very difficult because the assessment of the quality of life is related with subjective categories, what causes that direct inter-personal comparison of this category is doubtful [54]. In effect, the comparison of objective categories is needed to apply. These categories include the living standards. Between the quality of life and the living standards there is an essential difference in character of the assessment (objective and subjective). This caused that the precision of measurement was very important and sometimes decided on the 
quality of the results. However, to compare the living standard or - broader - the quality of life (whereas reservations described above), some indices are commonly used. We quote the two well-known ones: Human Development Index (HDI) and Quality of Life Index. Despite the usefulness, the critique of their structure and measure methods is broad [29], [41], especially as it concerns the single indices using for synthetic indicator's construction or areas taken into consideration. In the last case, in the subject literature one can observe more and more frequent underlying the environmental issues (or broad - sustainable development matters) which should be included into the construction of living standard's indicators [9], [31], [40], [45], [47]. The necessity of finding a new measurement of the living standard and quality of societies' life is emphasized by international organizations and especially scientists [35], [60]. In effect, there is a proposition of the Environmental Human Development Index, but it is not used so often in practice. Considering this, we have to underline that the direct assessment of living standard with relation to the sustainable development concept is very difficult and require an systematic operationalization of the appropriate indicators ${ }^{2}$. An example of an attempt of this approach in cross-border analysis of quality of life could be the research conduct by T. Borys, M. Kusterka-Jefmańska and the research team in 2012-2013 [5], [28]. They took into consideration the set of 6 different kinds of living satisfaction (with the state of: health, education, place of residence's safety, cultural and sports offer, financial and professional situation and with the place of residence) which were operated by using 43 detailed indicators (objective and subjective). The analysis was conducted on the base of direct interviews with 873 inhabitants of the district of Zgorzelec and the district of Görlitz. The most important factors influenced on the overall living satisfaction were the following: 1) on the Polish side - the satisfaction with the place of residence, with the financial and professional situation and with the state of health; 2) while on the German side of the bord - with the financial and professional situation and with education [28]. Among the detailed indicators used in this research and related with the environmental aspects influenced on quality of life and standard of living were: (1) access and condition of green areas, (2) image of the place of residence (cleanliness, aesthetics, etc.), (3) quality of drinking water, (4) waste management, (5) quality of the air, (6) state of the acoustic climate, (7) the ability to move around by bicycle or (8) by public transport. Here, worthy of underlining, the results of the research required the conducting of interviews and were not based on the public statistics data, what affects that the cyclical nature of such research depends only on the researchers' capabilities (without them it is impossible to compare the changes taking place). In other study conducted by A. Matušková, J. Preis and M. Rousová in selected Euroregions [32] the environmental aspects of quality of life was taken into consideration only cursorily, without conducting the detailed analysis. Based on this we could

2 For conducting in-depth analysis of relation between quality of life and environmental problems could be used various sets of them, ex. [55]. 
conclude, that environmental factors, are not so often analyzed in the cross-border research and therein is observed, an analytical gap for future surveys.

\section{Research Assumptions and Data Used to Analyze}

\subsection{The Limitation for Data Access}

The area covered by the analysis is the Carpathian Euroregion. It was established in 1993 by the decision of representatives of cross-border regional authorities of four countries: Poland (Podkarpackie region), Ukraine (Chernivets'ka oblast', Ivano-Frankivs'ka oblast', L'vivs'ka oblast' and Zakarpats'ka oblast'), Slovakia (Východné Slovensko) and Hungary (Észak-Alföld and Észak-Magyarország). In 1997 Romania joined the Eurergion (Centru, Nord-Est, Nord-Vest). The Euroregion is very diverse in many ways, and therefore - it is cognitively a very interesting area. The analysis of that kind of territory poses a lot of problems. In many cases, there is a lack of comparable data characterized the socio-economic situation on similar level of aggregation [46]. The Euroregion consists of the area both being a part of European Union (Hungary, Poland, Slovakia, Romania) as well as not belonging one (Ukraine). It makes impossible to obtain comparable data for the whole area, inter alia due to the different statistical standards of collecting data, lack of regional data, different requirements for elaborated reports or analyses, etc. The problem also results from different administrative divisions in each country and - in effect - different levels of areas includes of the Euroregion (most often the obligation to prepare the socio-economic reports lies on the equivalent of Polish voivodeships, and the Euroregion often consists of only fragments, e.g. part of the Central region and part of the Nord-Est region in Romania, so the data concerns the whole region, not the appropriate part only). It should be emphasized that the collection of data that concerns the Euroregion is periodically. In effect, there is a lack of data between the years 2017 and 2020. The last available comes from 2016, and next is supposed in 2021 (the data are collecting every four years). All this makes it difficult or - in some areas - even impossible to conduct an analysis, direct comparisons or propose the recommendations. It also negatively implies on elaboration of specific tools aimed at convergence, and limit the disparities between the regions. Only reliable and harmonized data allow for the creation of real economic and social programs for the development of euroregions [34].

The present work concerns spatial living standards. The literature on the subject underlines that in that kind of analysis even a several dozen indicators, grouped in appropriate categories, are used [1], [3], [14], [22], [36]. In the present paper we have collected 11 indices. It probably does not fully reflect the diversity of the area studied, but it allowed conducting the statistical analysis and gave the 
opportunity to formulate interesting conclusions. The analysis undertaken concerns living standard in the context of sustainable development, but this aspect appeared also problematic due to the lack of environmental data coming from the whole Euroregion area. For years' environmental aspects have been considered as the most complicated and problematic in the analysis of euroregions [34]. They were not included in the conducted analysis and the attention was paid to economic and social aspects such as two dimensions of sustainable development. Bearing in mind the previous comments (especially in the field of analysis of environmental aspects in cross-border surveys), for the future analysis we postulate to add a set of environmental indicators to public statistics surveys which allows to assess the sustainable development the Carpathian Euroregion in coherent way. It will require to choose the appropriate ones and accept them by the Steering Committee of National Statistics Offices responsible for delivering data concerning the Carpathian Euroregion, but in our opinion ensuring the providing the sustainable development data will be needed in nearest future due to the increasing the interest of this subject ${ }^{3}$ and the acceptance of the strategical dimension of this concept by the each countries.

\subsection{The Research Design}

The area covered by the analysis is the Carpathian Euroregion. The main thesis assumed in the article is the following: socio-economic changes affect the similarity of areas within the Euroregion. On this basis three hypothesis were accepted for testing:

$H_{1}$ - The most important changes were observed in social area.

$\mathrm{H}_{2}$ - The changes observed in economic area are significant for development of the Euroregion.

$H_{3}$ - The changes observed in economic area influence the social area.

To analyze the changes in the development process of the Carpathian Euroregion one of the cluster analysis - a multivariate comparative analysis method - was used. This method was described by Tryon [57] and developed by Cattell [10]. It allows dividing the units analyzed (the regions in the present paper) into similarly groups (clusters) based on multiple features. This statistical procedure leads to the extraction of a full hierarchy of clusters with a monotonically increasing level of similarity. The obtained, higher-order groups contain disjoint lower-level groups. In this kind of methods, each unit (a single element of a group) is initially a separate group, and then the number of existing groups is successively reduced, sequentially by joining them into higher-order groups. The procedure is completed when one group includes all analyzed units. The main advantage is the possibility

3 For example in "Acta Polytechnica Hungarica" some Authors took up topics related to environmental aspects [7], [24], [39]. 
to present the classification results in a compact graphic form using a connection tree (dendrogram), which illustrates subsequent connections of higher and higher order groups [20], [21]. In the present analysis, we use Ward's method (based on the analysis of variance approach) [21]. In this method, the sum of squared deviations of any two clusters (at each stage of the analysis) is minimized. Besides the multivariate analysis, it is also important to analyze the structure of each separated cluster, which allows to obtain information about what features decided to create individual clusters. In this context, the effective procedure is the arithmetic means method that consists of the following stages:

- Matrix calculation for the entire output of the arithmetic means of the following characteristics $\left(x_{i}\right)$,

- Calculation of arithmetical means for each clusters $\left(x_{n}\right)$,

- Calculation of structural ratio of each cluster which is given by quotient:

$\frac{x_{n}}{x_{i}}$

The verification of the assumed hypothesis was conducted using Wilcoxon matched pairs test, which allows to testify whether the level of analyzed variable changes in regions between two periods of time.

The last method that was used for the hypothesis verification is Spearman's Rank correlation coefficient, which takes values from the range between (-1) and (1). An interpretation of the coefficient is similar to Pearson's correlation coefficient, but Spearman's Rank correlation coefficient shows any monotonic relationship (also non-linear). The higher the value of the correlation coefficient, the greater the relationship between the variables. If the value is close to 0 , it means that there are no dependencies between them.

\section{An Analysis of Spatial Diversity of Living Standards in the Carpathian Euroregion}

For the study of living standards in the Carpathian Euroregion, 11 diagnostic variables were selected ([E] - means variables concern "economic" area and $[\mathrm{S}]-$ "social" area):

$x_{1}$ - natural increase per 1000 population [S]

$x_{2}$ - dwellings completed per 1000 population [S]

$x_{3}$ - students of higher education institutions per 10 thousand population [S]

$x_{4}$ - doctors per 10 thousand population [S]

$x_{5}$ - beds in general hospitals per 10 thousand population $[\mathrm{S}]$ 
$x_{6}$ - tourists accommodated totally per 1000 population $[\mathrm{S}]$

$x_{7}$ - gross domestic expenditures on R\&D activity in \% of GDP [E]

$x_{8}$ - Gross Domestic Product per capita in euro [E]

$x_{9}$ - ascertained crimes per 1000 population [S]

$x_{10}$ - employment rate $[\mathrm{E}]$

$x_{11}$ - unemployment rate $[\mathrm{E}]$

The availability of variables was accounted for the above choice. The analysis was carried out twice: for the year 2008 and 2016. Using descriptive statistics, the variables used for the study were characterized. Thanks to non-parametric Wilcoxon matched pairs test it was checked whether the accepted for the research features statistically significantly differed in levels during the analyzed period of time (Table $1 ; \boldsymbol{p}^{*}$ - statistically significant difference; $p<0.05$ ).

Table 1

The basic descriptive statistics of the examined diagnostic variables

\begin{tabular}{|c|c|r|r|c|r|r|r|}
\hline & \multicolumn{3}{|c|}{2008} & \multicolumn{3}{|c|}{2016} & \\
\hline Var. & $(\bar{x} \pm \sigma)$ & $V_{z}$ & \multicolumn{1}{|c|}{$K$} & $(\bar{x} \pm \sigma)$ & $V_{z}$ & \multicolumn{1}{c|}{$K$} & \multicolumn{1}{c|}{$p$} \\
\hline$x_{1}$ & $(-0.4 \pm 2.2)$ & -504.9 & -0.4 & $(-1.3 \pm 1.9)$ & -151.4 & 1.5 & $\mathbf{0 . 0 2 9 3} *$ \\
\hline$x_{2}$ & $(2.8 \pm 0.9)$ & 33.7 & 2.2 & $(2.3 \pm 1.2)$ & 50.4 & -0.6 & 0.1095 \\
\hline$x_{3}$ & $(365 \pm 126)$ & 34.6 & 3.4 & $(259 \pm 100)$ & 38.6 & 1.9 & $\mathbf{0 . 0 0 3 3} *$ \\
\hline$x_{4}$ & $(35.7 \pm 16.5)$ & 46.2 & -1.5 & $(38.2 \pm 14.5)$ & 38.0 & -1.1 & $\mathbf{0 . 0 4 6 8} *$ \\
\hline$x_{5}$ & $(74.6 \pm 15.7)$ & 21.0 & -0.3 & $(68.9 \pm 10.1)$ & 14.6 & 0.8 & 0.1095 \\
\hline$x_{6}$ & $(314.5 \pm 213.4)$ & 67.9 & -1.1 & $(511.8 \pm 309.3)$ & 60.4 & -0.2 & $\mathbf{0 . 0 0 3 3} *$ \\
\hline$x_{7}$ & $(0.4 \pm 0.2)$ & 56.2 & 1.0 & $(0.5 \pm 0.4)$ & 75.2 & 04 & 0.3739 \\
\hline$x_{8}$ & $(4129 \pm 2356)$ & 57.1 & -2.0 & $(5172 \pm 3396)$ & 65.7 & -1.6 & $\mathbf{0 . 0 4 0 8 *}$ \\
\hline$x_{9}$ & $(15.9 \pm 13.9)$ & 87.2 & 1.4 & $(14.1 \pm 5.6)$ & 40.0 & -0.6 & 0.8588 \\
\hline$x_{10}$ & $(51.6 \pm 5.3)$ & 10.3 & -1.1 & $(53.5 \pm 3.3)$ & 6.1 & 04 & 0.3065 \\
\hline$x_{11}$ & $(8.5 \pm 3.2)$ & 37.4 & -0.7 & $(7.8 \pm 2.9)$ & 37.4 & -0.1 & 0.7213 \\
\hline
\end{tabular}

Note: $\bar{x}-$ mean , $\sigma$-standard deviation, $V_{z}$ - variance coefficient, $K$ - kutrtosis coefficient

Source: own calculations

An average natural increase rate in the analyzed regions has negative values in both periods. Comparing these two values, we can state that the value has decreased and the difference is statistically significant $p<\alpha,(p=0.0293)$. In 2008 the smallest values were recorded in Hungary, in Észak-Magyarország (-4.1), and the highest in Slovakia - Východné Slovensko (3.4). Similarly, the extreme values were observed in the same regions in 2016 (-4.2 and 3.0). In 2008, the coefficient of variation of natural increase was very high $(-504.9 \%)$, what indicates significant variation and is additionally confirmed by the negative value of kurtosis. In 2016, the coefficient of variation decreased $(151 \%)$ and kurtosis changed the sign on positive, which means that the natural increase rates in the 
analyzed regions were more homogeneous. In most regions, the natural increase rate decreases, although in recent years there has been a slight increase in three regions: Východné Slovensko, Podkarpacie, Nord-West.

An analysis of the number of dwellings completed per 1000 population indicates that in year 2008, on average 3 dwellings per one thousand were completed while in 2016 only 2. The highest value of the indicator was recorded: in 2008 in Romania, in Nord-Vest region (5.0) and in 2016 in Poland, in Podkarackie region (4.0); the lowest value was recorded in Hungry in Észak-Magyarország region: (1.5) in 2008 and (0.3) in 2016. The large diversity was observed in 2016, which is evidenced by the high value of coefficient of variation and kurtosis. The conducted test shows that the changes in the indicator level were not statistically significant $(p=0.1095)$.

An average level of higher education students in 2008 amounted to 365 persons (per 10 thousand population) while in 2016 it decreased to the level of 259. The highest values were recorded in both years in Ukraine, in L'vivs'ka oblast' (accordingly: 679 and 493 persons). In 2008 the smallest value was noticed in Romania, in Nord-Est region (171) while in 2016 - in Hungary, in Észak-Alföld (151). The diversity between the regions increased in 2016 (in relation to the year 2008), which is evidenced by the high value of coefficient of variation and kurtosis. The was statistically significant difference between the values of indicator $(p=0.30033)$.

The next two variables concern the health care. Average number of doctors (per 10 thousand population) increased from 35.7 in 2008 to 38.2 in 2016. Larger diversity concerned this indicator was placed in 2008, later the data were more coherent. The smallest numbers of doctors were observed both in 2008 and in 2016 in Poland in Podkarpackie region (18.1 and 21.3), while the highest was observed in Ukraine, in 2008 in Chernivets'ka oblast' (61.8) and in IvanoFrankivs'ka oblast' $(60,9)$. The three Ukrainian regions: Chernivets'ka oblast', Ivano-Frankivs'ka oblast' and L'vivs'ka oblast' stand out definitely. During the analyzed period, the lowest values were observed in Podkarpackie region and in Romanian Nord-Vest region. The difference between number of doctors was statistically significant $p<\alpha(p=0.0468)$.

The second variable that concerns the health care is the number of beds in general hospitals per 10 thousand population. The analysis indicates that this variable was changed significantly in the analyzed period $\mathrm{p}>\alpha(\mathrm{p}=0.1059)$. The average amount of the indicator decreased in the analyzed period from 74.6 (2008) to 68.9 (2016). The lowest values were observed in Poland, in Podkarpackie (accordingly: 46.6 in 2008 and 48.6 in 2016) and the highest ones were observed in Ukraine, in Lvovska oblast (accordingly: 99.1 and 86.2). The diversity of the variable values decreased and the data became more homogeneous.

The variable responsible for the popularity of the region is the number of tourists accommodated totally per 1000 population. It testifies about public interests of the 
region, which can lead to an increase in the investment rate. An analysis shows that the increase that took place is statistically significant $p<\alpha(p=0.0033)$. The indicator increased in the analyzed period from 314.5 persons on 1000 population in 2008 to 511.8 persons in 2016. The least frequented by tourists region is Chernivets'ka oblast' in Ukraine (the rate of analyzed indicator amounted accordingly: in $2008-81$ people per 1000 population and in 2016 - 120 people per 1000 population). Most people used accommodation in 2008 in the Slovak region - Východné Slovensko (693) and in 2016 in Romania in the Centru region (1108 people per 1000 population). There is also the most aggressive increasing of the studied indicator.

The difference between the level of expenditures on $R \& D$ were not statistically significant in the analyzed period $p>\alpha(p=0.3739)$. An overall amount of expenditures for all regions increased slightly (from $0.4 \%$ in 2008 to $0.5 \%$ in 2016). The differentiation (disparities) between the level of indicator for each region increased. In 2008, the lowest value was observed in Romanian Centru region $(0.15 \%)$, while in 2016 in Ukrainian Ivano-Frankivs'ka oblast' $(0.09 \%)$. The highest level of expenditures were observed in Ukrainian L'vivs'ka oblast' and in Hungarian Észak-Alföld region (both 0.86\%), while in 2016 in Poland, in Podkarpackie region (1.29\%).

One of the most frequently analyzed indicators that reflects the level of development of a given country or region is Gross Domestic Product per capita. Within the test, the statistical signification of the difference between the level of the analyzed variable was examined. The test showed a significant increase in GDP in the analyzed regions $p<\alpha(p=0.0408)$ from $€ 4129$ in 2008 to $€ 5172$ in 2016. The highest values of GDP per capita were observed in Slovak in Východné Slovensko region (accordingly: € 6900 in 2008 and $€ 10200$ in 2016). The lowest - in Ukrainian Chernivets'ka oblast' (accordingly: $€ 1065$ and $€ 839$ ). The disparities in the surveyed regions in terms of GDP per capita increased significantly. Východné Slovensko region definitely stands out from the rest of the analyzed regions both in the level and the growth rate of the examined indicator.

The level of citizen security affecting the living standard was characterized by the indicator on ascertained crimes per 1000 population. The changes in the average level of examined indicator were not statistically significant $(p=0.8588)$. The average number of crimes decreased slightly from 15.9 in 2008 to 14.1 in 2016. The differentiation in the group of regions decreased. The highest number of crimes were ascertained in 2008 in Hungary in Észak-Alföld region (46.3) and in 2016 in Észak-Magyarország (23.8). The lowest number of assertion of the crimes took place in Ukrainian Ivano-Frankivs'ka oblast' (accordingly: 3.8 and 7.2).

The last two variables concern the labor market. The first one is an employment rate and the second one - an unemployment rate. Changes of both variables are not statistically significant. In relation to the employment rate, there was a slight increase in the average level (from 51.6 in 2008 to 53.5 in 2016). However, the 
variation between regions decreased. The highest rates of employment were observed in Ukrainian Zakarpats'ka oblast' (59.9) in 2008, and Romanian Nord Est region (58.7) in 2016. The lowest rates were noticed in Hungarian ÉszakMagyarország region (43.7) in 2008 and Romanian Centru (47.0) in 2016. Two Hungarian regions are definitely standing out. An increase of the employment rate was significant. These regions changed the ranking position from the last one in 2008 to the middle one in 2016. The unemployment rate increased between 2008 and 2012, then the rate decreased. The average level of this indicator amounted $8.5 \%$ (2008) and $7.8 \%$ (2016). The unemployment rate was the lowest in two Romanian regions: Nord-Vest and Nord-Est and the highest in Slovak in Východné Slovensko. The differentiation between regions has not changed.

From 11 chosen variables, only five were statistically significant, four out of them were related with "social" area and only one - with "economic". We can state, that the most important changes were observed in "social" area, and ipso facto the first hypothesis $\left(H_{1}\right)$ was confirmed for analyzed period of time. Due to this, the second hypothesis $\left(H_{2}\right)$ should be rejected.

\section{The Attempt to Assess the Living Standard in the Carpathian Euroregion in the Analyzed Period of Time}

Between variables, used for conducting the analysis of living standard, the correlation coefficients were calculated in purpose to check possible dependencies between them and possible removal of those which show high linear correlation. We use data from extreme years: the first (2008) and the last one (2016). Some dependencies changed the direction as in the case of the unemployment rate and the natural increase rate per 1000 population. In 2008, the correlation coefficient amounted (-0.25) but in year $2016-(0.76)$. The strength of the dependencies decreased (e.g. between the unemployment rate and tourists accommodated per 1000 population, from 0.57 in 2008 to $(-0.08)$ in 2016 . In result of the correlation analysis, we can state that there are no reasons to remove any of the variable adopted for the study. Depending on the studied period, they take different values.

Bag Plots show high dependencies between the unemployment rate and ascertained crimes per 1000 population and the employment rate (Figure 1). It is possible to observe that the strength and the direction of dependencies in two analyzed years changed significantly. 

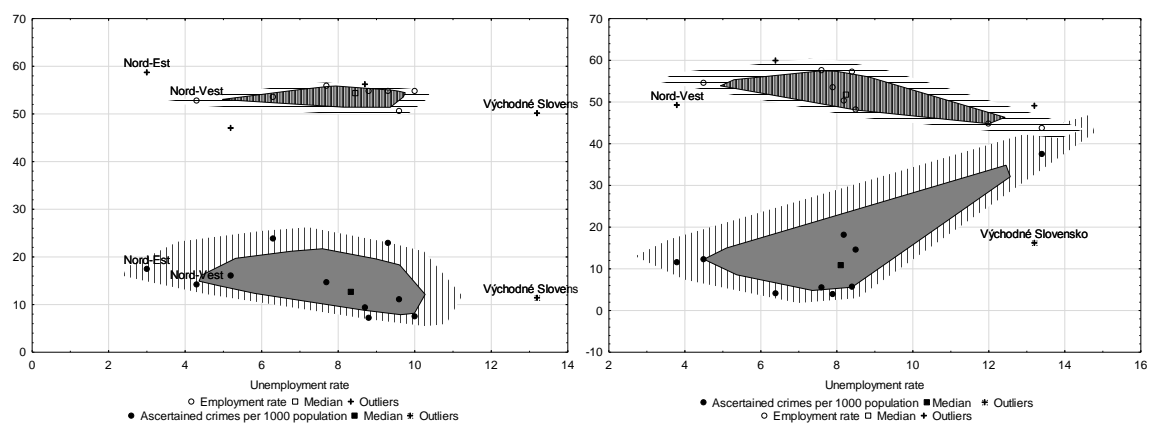

Figure 1

Relations between the unemployment rate $\left(x_{11}\right)$ and the rate of ascertained crimes per 1000 population $\left(x_{9}\right)$ and the employment rate $\left(x_{10}\right)$ in 2008 and 2016

Source: own elaboration

The studied areas of the Carpathian Euroregion were subjected to the grouping procedure using the Ward's method to isolate the groups of regions similar to each other in terms of diagnostic features (selected for testing). The results of the grouping are presented in Figure 2 and Table 3.
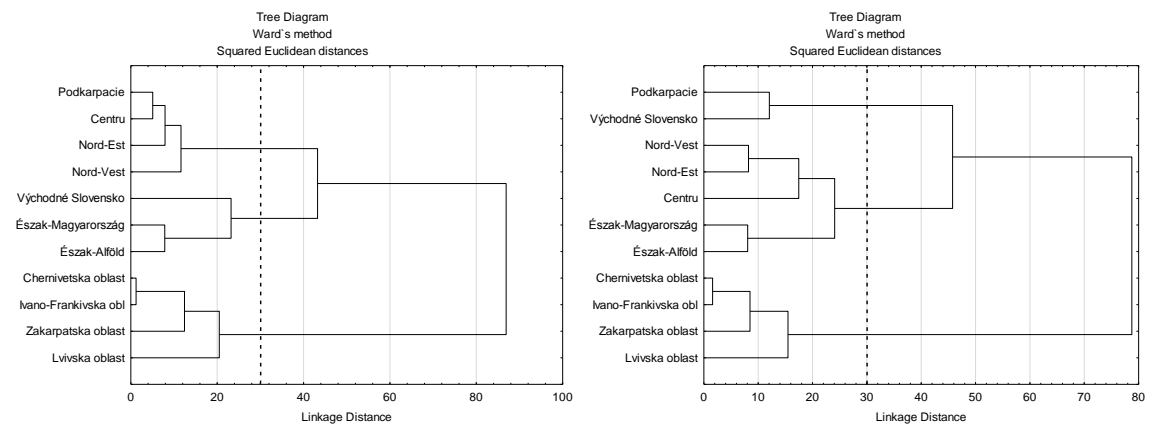

Figure 2

Tree diagram - Ward's Method for clusters in 2008 and 2016

Source: own elaboration

Both, in 2008 and 2016, three groups of regions similar to each other in the scope of the inhabitants' living standard were identified (with the use of the characteristics selected for the research). The first two groups changed the number of regions, while the third group remained unchanged. In 2008, the region from Poland (Podkarpackie) was similar to the Romanian regions (Centru, Nort-Vest, Nord-Est) while in 2016 only the region from Poland and Slovakia (Východné Slovensko) formed one cluster, while the Romanian regions merged with the Hungarian ones (Table 2). 
Table 2

The assignment of regions to the appropriate group (for year 2008 and year 2016)

\begin{tabular}{|c|l|c|l|}
\hline Gr. & \multicolumn{1}{|c|}{ 2008 - Country: Region } & Gr. & \multicolumn{1}{|c|}{ 2016 - Country: Region } \\
\hline A & $\begin{array}{l}\text { PL: Podkarpacie, } \\
\text { RO: Centru, Nord-Vest, Nord-Est }\end{array}$ & A & $\begin{array}{l}\text { PL: Podkarpacie } \\
\text { SK: Východné Slovensko }\end{array}$ \\
\hline B & $\begin{array}{l}\text { HU: Észak-Magyarország, Észak-Alföld } \\
\text { SK: Východné Slovensko }\end{array}$ & B & $\begin{array}{l}\text { RO: Nord-Vest, Nord-Est, Centru } \\
\text { HU: Észak-Alföld, Észak-Magyarország }\end{array}$ \\
\hline C & $\begin{array}{l}\text { UKR: Zakarpats'ka oblast', } \\
\text { Chernivets'ka oblast', Ivano-Frankivs'k 'k } \\
\text { oblast', L'vivs'ka oblast' }\end{array}$ & $\begin{array}{l}\text { CKR: Zakarpats'ka oblast', } \\
\text { Chernivets'ka oblast', Ivano-Frankivs'ka } \\
\text { oblast', L'vivs'ka oblast' }\end{array}$ \\
\hline
\end{tabular}

Source: own elaboration

For the separated clusters, an analysis of group averages was carried out in purpose to check which variables determined the resulting clusters (Table 3 and Figure 3).

Table 3

Dominant variables in each group for year 2008

\begin{tabular}{|c|c|c|c|}
\hline Year & $\mathrm{A}$ & $\mathrm{B}$ & $\mathrm{C}$ \\
\hline & \multicolumn{3}{|c|}{ The highest value of variable } \\
\hline 2008 & $x_{1}, x_{2}$ & $x_{6}, x_{7}, x_{8}, x_{9}, x_{11}$ & $x_{3}, x_{4}, x_{5}, x_{10}$ \\
\hline 2016 & $x_{1}, x_{2}, x_{7}, x_{8}, x_{11}$ & $x_{6}, x_{9}$ & $x_{3}, x_{4}, x_{5}, x_{10}$ \\
\hline & \multicolumn{3}{|c|}{ The lowest value of variable } \\
\hline 2008 & $x_{4}, x_{5}, x_{7}, x_{11}$ & $x_{1}, x_{2}, x_{3}, x_{10}$ & $x_{6}, x_{8}, x_{9}$ \\
\hline 2016 & $x_{3}, x_{4}, x_{5}, x_{10}$ & $x_{1}, x_{2}, x_{11}$ & $x_{6}, x_{7}, x_{8}, x_{9}$ \\
\hline
\end{tabular}

Source: own elaboration

In 2008, the "A" group included the areas from Poland and Romania. They were characterized by high rates of: natural increase $\left(x_{1}\right)$, dwellings completed per 1000 population $\left(x_{2}\right)$. The lowest values were assumed here by indicators regarding: R\&D expenditures $\left(x_{7}\right)$ and unemployment $\left(x_{11}\right)$, as well as the indictors related with health care [numbers of doctors $\left(x_{4}\right)$ and numbers of beds in hospitals $\left(x_{5}\right)$, both per 10 thousand. population). The levels of analyzed indicators for all clusters are shown in Figure 3. In 2016, the "A" group included Podkarpackie and Východné Slovensko. These regions were characterized by the highest rate of natural increase $\left(x_{1}\right)$ and dwellings completed per 1000 population $\left(x_{2}\right)$. The highest were also expenditures on $\mathrm{R} \& \mathrm{D}\left(x_{7}\right)$ and GDP per capita $\left(x_{8}\right)$. Unfortunately, the rate of unemployment $\left(x_{11}\right)$ was also high, as well as the condition of health care was bad [number of doctors $\left(x_{4}\right)$ and beds in general hospitals per 10 thousand population $\left(x_{5}\right)$ were very low]. Also, the employment rate $\left(x_{10}\right)$ and the number students of higher education institutions $\left(x_{3}\right)$ were low.

In 2008 , in the group "B" there are two Hungarian and one Slovakian regions. These areas were characterized by a very low rate of natural increase $\left(x_{1}\right)$, the fewest number of flats given for use $\left(x_{2}\right)$, number of students $\left(x_{3}\right)$ and the 
employment rate $\left(x_{10}\right)$ was the lowest from all the analyzed factors. The most significant indicators (the highest values) were that of tourists accommodated total per 1000 population $\left(x_{6}\right)$, R\&D expenditure $\left(x_{7}\right)$, GDP per capita $\left(x_{8}\right)$ and ascertained crimes $\left(x_{9}\right)$. Unfortunately, the unemployment rate $\left(x_{11}\right)$ also took the highest value. In 2016, in "B" cluster there were Hungarian and Romanian regions. These areas had the highest values of tourists accommodated total per 1000 population $\left(x_{6}\right)$ and ascertained crimes $\left(x_{9}\right)$. Whereas, on the lowest level was a natural increase $\left(x_{1}\right)$ and dwellings completed $\left(x_{2}\right)$. The unemployment rate $\left(x_{11}\right)$ was also the lowest in these regions.

In 2008, the "C" cluster was composed of Ukrainian regions. These areas were characterized by a negative natural increase rate $\left(x_{1}\right)$, the lowest value of GDP per capita $\left(x_{8}\right)$, as well as the lowest value of ascertained crimes $\left(x_{9}\right)$. On the other hands the indictors related to health care took the highest values $\left(x_{4}, x_{5}\right)$, as well as students of higher education institutions $\left(x_{3}\right)$ and the employment rate $\left(x_{10}\right)$. The analysis conducted for the year 2016 confirmed the uniformity of Ukrainian regions that still stick together. The health care indicators $\left(x_{4}, x_{5}\right)$ were one of the highest, together with the number of students $\left(x_{3}\right)$ and - the highest among all clusters - the employment rate $\left(x_{10}\right)$. The lowest values of indicators were observed for accommodated tourists $\left(x_{6}\right)$, expenditures on R\&D $\left(x_{7}\right)$ and GDP per capita $\left(x_{8}\right)$. In that regions also the number of ascertained crimes $\left(x_{9}\right)$ were the lowest.

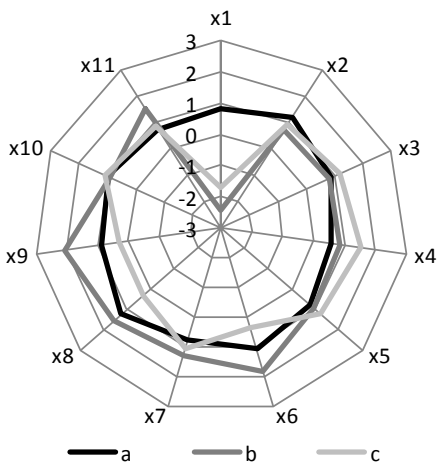

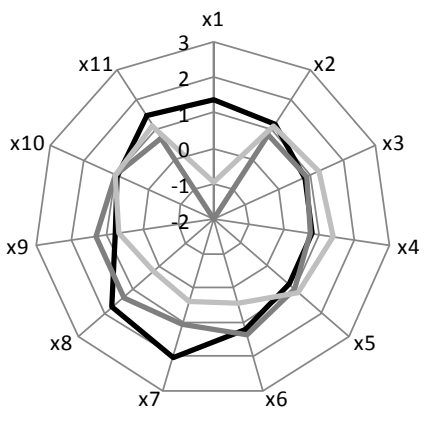

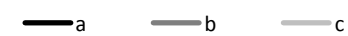

Figure 3

The indicators of group averages in analyzed clusters

Source: own elaboration

Using Spearman's Rank correlation, the existence of relation between "social" and "economic" area was verified. Based on the variables used within the present analysis, the new synthetic variables were formulated: one for "economic" matters and the other one - for "social". The synthetic variable indicator ranges from 0 to 1. The high value of that indicator, the higher level of "social" or "economic" area. The analysis indicated, that in 2008 the Spearpman's Rank correlation coefficient $\left(R_{S}\right)$ was not statistically significant $p>\alpha(p=0.7495)$ and the value 
amounted $R_{S}=0.11$, which means the lack of any relation between synthetic variables. Whereas in 2016, the coefficient amounted $R_{S}=(-0.71)$ and was statistically significant $p<\alpha(p=0.0352)$. Since the dependence is negative, as the level in the economic area increases, the value of the indicator in the social area decreases (Figure 4).
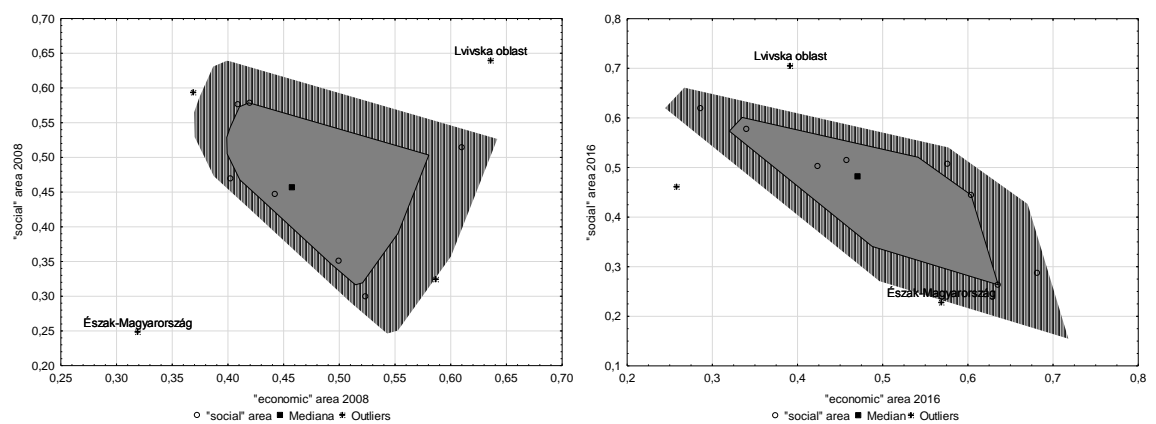

Figure 4

The relations between "economic" and "social" area in 2008 and 2016

Source: own elaboration

As the result the third hypothesis $\left(H_{3}\right)$ was not confirmed for the analysis of the year 2008, but the assumed dependence was confirmed for the year 2016. To confirm whether this dependence is indeed permanent, the analysis for the next periods is needed (e.g. for year 2020 what could be a contribution to further research).

\section{Conclusions}

This study presents an analysis of the spatial diversity of the living standards of the inhabitants of the Carpathian Euroregion, comparing two periods of 2008 and 2016 in the context of sustainable development. However, this article is the second one that is concerned with the subject of the living standard of the Carpathian Euroregion's inhabitants [44], however, we take into consideration the sustainability elements and consider the linkages between them. The analysis, both theoretical (based on the subject's literature) and empirical (with using the statistical data) allows us to state that there is a need to deepen the consideration concerning sustainable development and quality of life, as well as, the linkage between them. These two immeasurable categories, with a broad definition (and ways to understand) require preparation of a coherent proposition of the measurement method. Actually, we could only observe (finally draw the conclusion) a limited number of aspects related with the categories mentioned. Based on the example, which refers to our assumed hypothesis, we could state that for the Euroregion's development, the "social" area is more important than the "economic" one, and - what could be surprising - the "economic" sphere could have a negative influence on the "social" one. Our considerations concerned, also, 
the need of using the environmental aspects and the limitations for data access. These elements probably will require preparation of a new methodology of measurement (including collecting and aggregation of the data), but in our opinion, it is needed, to conduct a wide range analysis. Conducting a common development policy requires using a common base (e.g. definitions, data, reports, etc.). Proposition of adequate improvements should lead to the development of the area, but it is impossible to achieve without a coherent framework. An increase of the living standard is a common goal for all societies, despite the borders (both Country or EU). We hope that our analysis will be taken as a suggestion, to make an effort, aiming at elaboration of an appropriate set of indicators, describing our development in the context of sustainability.

\section{Acknowledgments}

This research was co-funded by the grants from the Ministry of Education and Science of Ukraine (No 0120U102002, No0120U102001).

\section{References}

[1] Alborz A.: The Nature of Quality of Life: A Conceptual Model to Inform Assessment, Journal of Policy and Practice in Intellectual Disabilities, 2017, 14(1): 15-30

[2] Barrera-Roldán A., Saldívar-Valdés A.: Proposal and application of a Sustainable Development Index, Ecological Indicators, 2002, 2: 251-256

[3] Biagi B., Ladu M. G., Meleddu M., Royuela V.: Tourism and the city: The impact on residents' quality of life, International Journal of Tourism Research, 2020, 22(2): 168-181

[4] Beckerman W.: Sustainable Development: Is it a Useful Concept?, Environmental Values, 1994, 3(3): 191-209

[5] Borys T., Knippschild R. (eds): Jakość życia w obszarze przygranicznym wzmocnienie ponadgranicznych przepływów dla wspólnego zrównoważonego rozwoju i planowania regionalnego, Ad Rem, Jelenia Góra, 2014

[6] Brown, B. J., Hanson, M. E., Liverman, D. M., Merideth R. W. Jr.: Global sustainability: Toward definition. Environmental Management, 1987, 11: 713-719

[7] Brożyna J., Mentel G., Szetela B., Renevable Energy and Economic Development in the European Union. Acta Polytechnica Hungarica, 2017, 14(7): $11-34$

[8] Brundtland G. H.: Our Common Future. Report of the World Commission on Environment and Development, United Nations, 1987

[9] Busato F., Maccari N.: The Environmental Human Development Index, Rivista di Studi Sulla Sostenibilita', 2016, 14: 31-44 
[10] Cattell R. A.: Note on correlation clusters and cluster search methods, Psychonometrica, 9, 1944, pp. 169-184

[11] Ciegis R., Ramanauskiene J., Martinkus B., The Concept of Sustainable Development and its Use for Sustainability Scenarios, Inzinerine Ekonomika-Engineering Economics, 2009, 62(2): 28-37

[12] Constantinescu A., Platon V.: Sustainable development paradigm synopsis, Annals of the University of Oradea, Economic Science Series, 2014, 23(1): 116-124

[13] Diaz- Sarachaga J. M., Jato- Espino D., Castro- Fresno D.: Is the Sustainable Development Goals (SDG) index an adequate framework to measure the progress of the 2030 Agenda?, Sustainable Development, 2018, 26: 663-671

[14] Dziubińska-Michalewicz M.: Wybrane wskaźniki poziomu życia - analiza porównawcza Polski i RFN, Kancelaria Sejmu, 2002, 895

[15] Emas R.: The Concept of Sustainable Development: Definition and Defining Principles, GDRS report 2015, Florida International University 2015

[16] Fyliuk, H., Honchar, I., \& Kolosha, V.: The Interrelation between Economic Growth and National Economic Competitiveness: The Case of Ukraine. Journal of Competitiveness, 2019, 11(3): 53-69

[17] Fiedor B., Czaja S., Graczyk A., Jakubczak Z.: Podstawy ekonomii środowiska i zasobów naturalnych, C. H. Beck, Warsaw 2002

[18] Gibson R. B.: Sustainability assessment: basic components of a practical approach, Impact Assessment and Project Appraisal, 2006, 24(3): 170-182

[19] Giddings B., Hopwood B., O'Brien G.: Environment, economy and society: fitting them together into sustainable development, Sustainable Development, 2002, 10: 187-196

[20] Ginevicius, R.: Quantitative Assessment of the Compatibility of the Development of Socioeconomic Systems. Journal of Competitiveness, 2019, 11(2): 36-50

[21] Grabiński T.: Metody taksonometrii, Publisher of the Cracow University of Economics, Cracov 1992

[22] Hancock S., Wells Y.: The change in quality of life for older Australians: A rural and urban comparison, Australian Journal of Rural Health, 2019, 27

[23] Hansmann R., Mieg H. A., Frischknecht P.: Principal sustainability components: empirical analysis of synergies between the three pillars of sustainability, International Journal of Sustainable Development \& World Ecology, 2012, 19(5): 451-459 
[24] Hrbáčková L., Stojanović A., Tuček D., Hrušecká D., Environmental Aspects of Product Life Cycle Management and Purchasing Logistics: Current Situation in Large and Medium-Sized Czech Manufacturing Companies. Acta Polytechnica Hungarica, 2019, 16(7): 79-94

[25] Hope J.: Globalising sustainable development: Decolonial disruptions and environmental justice in Bolivia, Area, 2020 (Early View):1-9

[26] Hopwood B., Mellor M., O'Brien G.: Sustainable development: mapping different approaches, Sustainable Development, 2005, 13: 38-52

[27] Johnston P., Everard M., Santillo D., Robèrt K. H.: Reclaiming the definition of sustainability. Environmental Science and Pollution Research International, 2007, 14(1): 60-66

[28] Kusterka-Jefmańska M., Determinanty jakości życia w kontekście badań transgranicznych. Studia i Prace Wydziału Nauk Ekonomicznych i Zarządzania, Uniwersytet Szczeciński, 2015, 40(2): 251-261

[29] Kovacevic M.: Review of HDI Critiques and Potential Improvements. Human Development Research Paper, 2010, 33

[30] Lee K.: Global sustainable development: its intellectual and historical roots. In Global Sustainable Development in the $21^{\text {st }}$ Century, Lee K., Holland A., McNeill D. (eds), Edinburgh University Press, Edinburgh 2000: 31-47

[31] Maccari N.: Environmental sustainability and Human Development: a greening of Human Development, Working Paper available at SSRN, 2014

[32] Matušková A., Preis J., Rousová M., Quality of Life and Cross-Border Relations in Selected Czech Euroregions, In T. Havlíček et al. (eds.), Borders in Central Europe After the Schengen Agreement, Springer 2018: 179-196

[33] Meadows D., Meadows D., Randers J., Behrens W.W.: The limits to growth, Universe Books, New York 1972

[34] Metodyczne i praktyczne problemy statystyki Euroregionów, Statistics Poland, Warsaw-Jelenia Góra 1994

[35] Migała-Warchoł A., Szczygieł E.: Classification of the European Union countries with an application of the modified Human Development Index, SGEM2018 Conference Proceedings, 2018, 5(3.3): 87-94

[36] Migała-Warchoł A.: Ocena zróżnicowania poziomu życia mieszkańców województwa podkarpackiego, In Metody Ilościowe w Badaniach Ekonomicznych, 2010, XI/2: 222-321

[37] Munasinghe M.: Environmental Issues and economic Decisions in Developing Countries, World Development, 1993, 21(11): 1720-1748

[38] Murphy K.: The social pillar of sustainable development: a literature review and framework for policy analysis, Sustainability, 2012, 8(1): 15-29 
[39] Németh-Katona J., Biologically Qualified Environment, Ecologically Evaluated Conditions. Acta Polytechnica Hungarica, 2008, 5(3): 101-104

[40] Neumayer E.: The human development index and sustainability - a constructive proposal, Ecological Economics, 2001, 39: 101-114

[41] Noorbakhsh F.: The Human Development Index: some technical issues and alternative indices, Journal of International Development, 1998, 10: 589605

[42] Phillis Y.A., Andriantiatsaholiniaina L.: Sustainability: an ill-defined concept and its assessment using fuzzy logic, Ecological Economics, 2001, 37(3): 435-456

[43] Piecuch T., Chudy-Laskowska K.: Jakość życia przedsiębiorców ze szczególnym uwzględnieniem kobiet prowadzących działalność gospodarczą, Studia i Materiały. Miscellanea Oeconomicae, 2007, 21(3): 343-354

[44] Piecuch T., Chudy-Laskowska K., Szczygieł E.: The living standard of the inhabitants of the Carpathian Euroregion, Production Management and Business Development, B. Mihalčová, P. Szaryszová, L. Štofová, M. Pružinský, B. Gontkovičová (eds.), CRC Press Taylor \& Francis Group, Leiden 2019: 179-184

[45] Rudra A., Chattopadhyay A.: Environmental change of coastal Sundarbans: Impact on livelihood and standard of living status of indigenous people, Environmental Quality Management, 2019, 29(2): 77-84

[46] Potencjał społeczno-gospodarczy Euroregionu Karpackiego 2008-2010, Statistics Poland branch Rzeszow, Rzeszow 2012

[47] Ranis G., Stewart F., Samman E.: Human Development: Beyond the Human Development Index, Journal of Human Development, 2006, 7(3): 323-358

[48] Rapley M.: Quality of Life Research: A Critical Introduction, SAGE Publications, London 2003

[49] Robinson J.: Squaring the Circle? Some Thoughts on the Idea of Sustainable Development, Ecological Economics, 2004, 48: 369-384

[50] Rogall H.: Ekonomia zrównoważonego rozwoju. Zysk \& S-ka, Poznan 2010

[51] Spangenberg J.H., Bonniot O.: Sustainability indicators: A compass on the road towards sustainability, Wuppertal Papers 1998, 81

[52] Stiglitz J. E., Sen A., Fitoussi J-P.: Report by the commission on the measurement of economic performance and social progress, 2009

[53] Stigt R. van, Driessen P., Spit T.: On the Necessity of an Integrated, Participative and Adaptive Approach to Sustainable Urban Environmental 
Quality Planning, Environmental Policy and Governance, 2017, 27: 193206

[54] Szczygieł E.: Ocena użyteczności dochodu i jej wpływ na oszczędności gospodarstw domowych, WNT, Warsaw 2014

[55] Tartaglia S., Conte E., Rollero Ch.: The influence of coping strategies on quality of life in a community facing environmental and economic threats, Journal of Community Psychology, 2018, 46: 251-260

[56] Theofilou P.: Quality of Life: Definition and Measurement. Europe's Journal of Psychology, 2013, 9(1): 150-162

[57] Tryon R.: Cluster Analysis, McGraw-Hill, New York 1939

[58] United Nations, Declaration of the United Nations Conference on the Human Environment, Stockholm 1972

[59] Volchik, V., Oganesyan, A., Olejarz, T.: Higher education as a factor of socio-economic performance and development. Journal of International Studies, 2018, 11(4): 326-340

[60] Zakrzewska B.: Zrównoważony rozwój a jakość życia, Autobusy: technika, eksploatacja, systemy transportowe, 2019, 229(4): 38-41

[61] Zikic S.: A modern concept of sustainable development. Progress in Economic Sciences, 2018, 5: 143-151

[62] Zainol, N. R., Al Mamun, A., Ahmad, G., \& Simpong, D. B.: Human Capital and Entrepreneurial Competencies towards Performance of Informal Microenterprises in Kelantan, Malaysia. Economics and Sociology, 2018, 11(4): 31-50

[63] Zarghami E., Fatourehchi D., Karamloo M.: Impact of Daylighting Design Strategies on Social Sustainability Through the Built Environment, Sustainable Development, 2017, 25: 504-527

[64] Zielińska A.: Comparative Analysis of Circular Economy Implementation in Poland and other European Union Countries. Journal of International Studies, 2019, 12(4): 337-347

[65] Živčicová, E., Bulková, K., Masárová, T.: Comparison of the Selected Indicators of Work Life Balance in European Union Countries, Economics and Sociology, 2017, 10(1): 222-231 